\title{
SALVAGE LOGGING AND REPLANTING REDUCE UNDERSTORY COVER AND RICHNESS COMPARED TO UNSALVAGED-UNPLANTED SITES AT MOUNT ST. HELENS, WASHINGTON
}

\author{
J.H. Titus ${ }^{1}$ and E. Householder ${ }^{2}$
}

\begin{abstract}
The 1980 eruption of Mount St. Helens killed trees in a broad 600-km² swath north of the crater. Over most of the blast zone, dead trees were salvage logged and Abies procera was planted, except in areas within the Mount St. Helens National Volcanic Monument. We compared salvage-replanted sites and unsalvaged sites in 1 area of the blast zone where the sites were adjacent by using twenty-five $200-\mathrm{m}^{2}$ plots for each treatment. Salvaged-replanted plots had significantly lower herb and shrub cover, richness, diversity, litter depth, downed woody debris, nitrate, and phosphate. Salvaged-replanted sites also had significantly more stumps, bare area, and moss cover than unsalvaged plots. Soil organic matter and nonnative species cover did not differ. Nonnative species were not important components of any plots. Nitrate, total nitrogen, organic matter, and litter were correlated with the major patterns of species distribution in a canonical correspondence analysis of the salvaged-replanted plots. In the unsalvaged plots, slope, downed woody debris, and elevation were correlated with the major patterns of species distribution.
\end{abstract}

Key words: volcano, succession, pumice, noble fir.

The massive 1980 lateral eruption of Mount St. Helens, Washington, destroyed or altered forests within the blast zone and blanketed vast areas with airborne tephra. Beyond the zone of complete destruction, trees were knocked down and killed by the eruption, but some seedlings and saplings survived under snow and were able to emerge through the deposited tephra. Still further away from the crater, trees were killed by the eruption but remained standing. In 1982 the 44,550-ha Mount St. Helens National Volcanic Monument was established to preserve the effects of the eruption of Mount St. Helens and to allow natural successional processes to occur. However, the majority of the impacted landscapes were outside of the monument. Those lands that were unlogged at the time of the eruption were subsequently salvage logged in 1980-1982 and planted in Abies procera at higher elevations and in Pseudotsuga menziesii and Pinus monticola at lower elevations between 1981 and 1987. The unsalvaged sites on Mount St. Helens compose a large, slowly reforesting area, which is important for bird, amphibian, and mesopredator biodiversity (Dale et al. 2005). Recently, naturally disturbed, unplantedunsalvaged forest that is undergoing natural succession has been considered the rarest condition on forest lands in the Pacific Northwest (Franklin et al. 2000). The proximity of unsalvaged sites and salvaged-replanted sites provides a unique opportunity to observe differences in forest development under these 2 management options.

Large-scale natural disturbances that impact forests are common worldwide. The recouping of economic losses due to large-scale forest disturbance is usually attempted by salvaging the timber; for example, salvage logging has ensued following large wildfires and windstorms in southeastern Asia, Australia, and North America (van Nieuwstadt et al. 2001, Lindenmayer et al. 2004, Donato et al 2006). The ecological consequences of salvage logging and whether it actually helps forests recover are debated (McIver and Starr 2000, Lindenmayer et al. 2004, Donato et al. 2006, Stokstad 2006). Forest managers must decide to salvage-log and replant, to leave disturbed areas to recover on their own, or to possibly replant without salvage logging. Under the recently passed federal Healthy Forests Restoration Act (available from: http://www.fs.fed.us/ projects/hfi/field-guide/), much more salvage logging is planned for federal forest lands that

\footnotetext{
1Department of Biology, Jewett Hall, SUNY-Fredonia, Fredonia, NY 14063. E-mail: titus@fredonia.edu

${ }^{2}$ Department of Biology, Texas Christian University, Fort Worth, TX 76129.
} 
have been disturbed by fire, wind, insects, disease, and so forth. Thus, it is important to understand how these management choices impact disturbed forested ecosystems.

Summer temperatures in soils of unsalvaged areas are $5^{\circ} \mathrm{C}$ cooler than in soils in salvagelogged areas (Rumbaitis-del Rio 2006). Trees downed by storms provide shade to vegetation, including surviving tree seedlings; salvage logging removes these downed trees. Likewise, trees killed by wildfire and left standing provide shade, which slows heating of the soil surface (Amaranthus et al. 1989). Thus, snags and downed woody debris (DWD) modify surface microenvironmental conditions. Dead trees are also a source of large woody debris for streams (Amaranthus et al. 1989).

Post-fire salvage logging in southwestern Oregon reduced natural conifer regeneration due to soil disturbance and burial, and increased downed woody fuel loads thereby possibly raising reburn risk (Donata 2006). Salvage logging caused high seedling mortality in a coniferous subalpine forest damaged by a windstorm in Colorado (Rumbaitis-del Rio 2006). The unsalvaged sites had greater herb and shrub cover and diversity than salvaged sites, which showed a shift towards graminoid dominance (Rumbaitis-del Rio 2006). Eleven years after logging, shrub cover was higher and forb cover was lower on unsalvaged sites than on salvaged sites (Stuart et al. 1993, Sexton 1994). In northwestern California, community composition in Douglas-fir forests was strongly affected by post-fire salvage logging, including marked differences in life-forms of the dominant species; however, species diversity was not affected. Hardwood dominance on salvaged sites may continue for a long time to come because hardwoods inhibit establishment of Douglas-fir and thereby prevent succession to open-canopy Douglas-fir forest, which occurs on post-burn unsalvaged sites (Stuart et al. 1993).

Documented effects of salvage logging on soil erosion and soil nutrient loss have been variable. For example, several studies (Chou et al. 1994a; 1994b; Helvey et al. 1985) found that erosion increased with salvage logging, whereas others found no difference between logged and unlogged sites (Marston and Haire 1990, Maloney et al. 1995). These disparate findings may arise because of the wide array of environmental conditions, forests, salvage- logging techniques, and research methods. Vegetation removal and soil disturbance caused by post-fire salvage logging may have created the conditions for colonization by nonnative ruderal plant species in Florida scrub (Greenberg et al. 1995). Likewise, nonnative-species cover and richness were slightly higher on salvage-logged sites in Oregon (Sexton 1994).

Thus, salvage logging after fire can reduce vegetation biomass, increase nonnative plant species cover, increase graminoid cover, reduce overall plant species richness, and decrease the growth of post-disturbance tree regeneration in the 1st years after logging. At present, information on the environmental effects of salvage logging remains scanty (McIver and Starr 2000, Donato et al. 2006). We are still far from detecting similar responses to the impacts of salvage logging across systems. All species have evolved in the presence of disturbance, and frequent disturbances such as fire and wind should not result in a long-term change to the fundamental character of a system. However, more serious consequences may possibly result from compounded perturbations within the normal recovery time of a community (Paine et al. 1998, van Nieuwstadt et al. 2001). Thus, after multiple perturbations communities may be deflected into alternative stable states. This study addresses differences in herb and shrub vegetation and soils in 1 area of the blast zone between adjacent salvaged-replanted sites and unsalvaged sites 23 years after the eruption of Mount St. Helens. Differences between the 2 treatments are due to the combined influence of salvage logging and replanting in comparison to unsalvaged-unplanted sites.

\section{Methods}

The lateral eruption on 18 May 1980 created a wide range of disturbance, primarily to the north of Mount St. Helens $\left(46^{\circ} 12^{\prime} \mathrm{N}\right.$, $122^{\circ} 11^{\prime} \mathrm{W}$; Fig. 1). Climate is maritime, with cool, wet winters and warm, dry summers. Annual precipitation fluctuates widely around a mean of $237 \mathrm{~cm}$; drought is common during July and August; and mean temperatures range from a $-4^{\circ} \mathrm{C}$ minimum to a $0^{\circ} \mathrm{C}$ maximum in January and a $7^{\circ} \mathrm{C}$ minimum and a $22^{\circ} \mathrm{C}$ maximum in August (Swanson et al. 2005).

The area near Meta Lake was used for this study because salvaged-replanted and unsalvaged areas are adjacent, with the most distant 

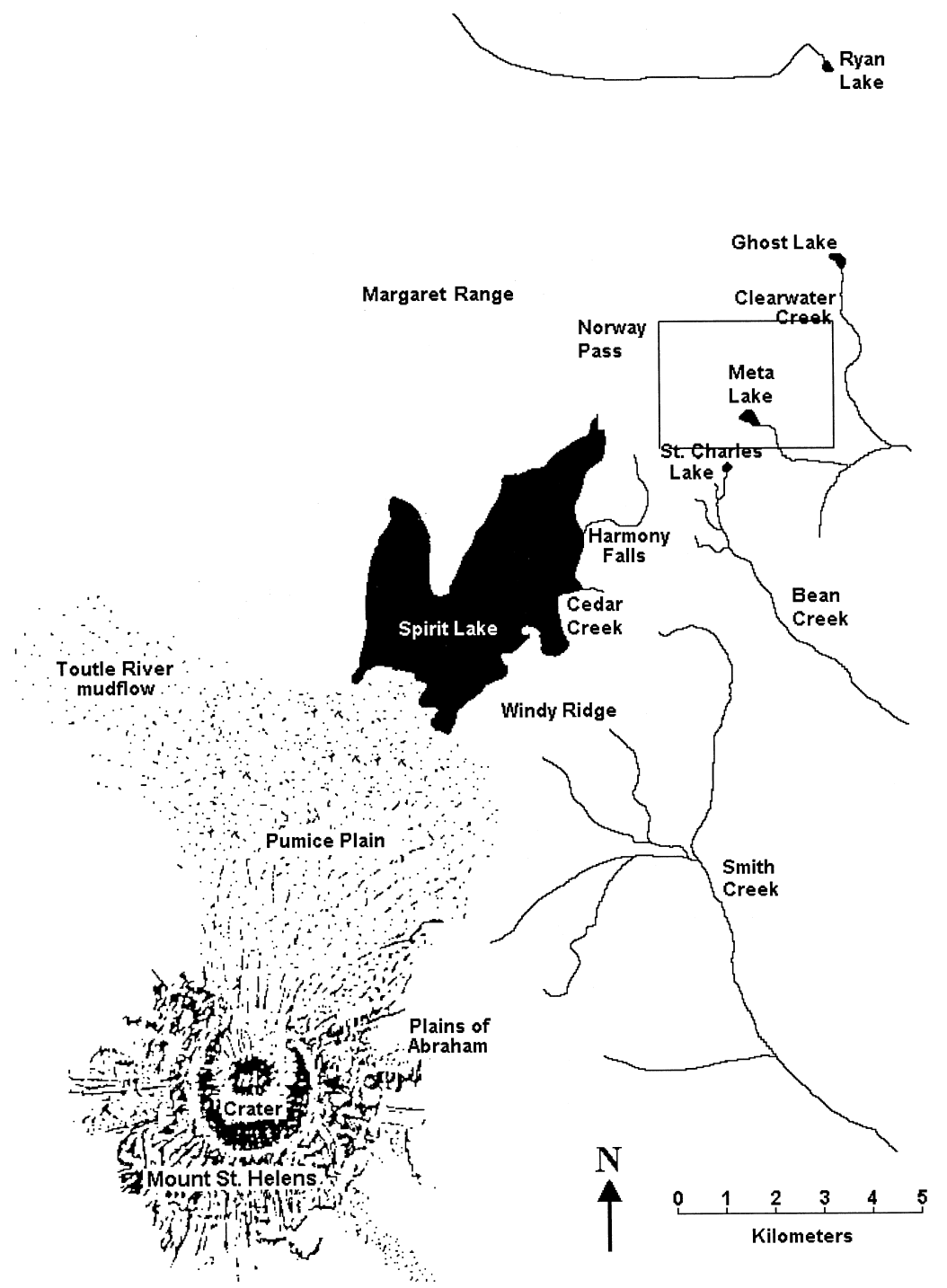

Fig. 1. Study area on Mount St. Helens, Washington. The square drawn on the map approximates the study area with unsalvaged plots on the west side and salvaged-replanted plots to the east.

plots being $<3 \mathrm{~km}$ apart (Fig. 1). Thus, preeruption differences between plots were presumably not large. We sampled only sites believed to have been old growth before the eruption. Stumps and logs blown down in the direction of the blast were used as evidence. However, some plots, or portions of some plots, may have been clearcut prior to the eruption. Tephra approximately $15-30 \mathrm{~cm}$ deep was deposited over the study area by the eruption. Tephra deposits are extremely nutrient poor and contain very low concentrations of carbon, nitrogen, and phosphorus (Titus unpublished data). This area was ground-salvaged in 19811982 and planted in Abies procera in 19821984. Planting density and survival of planted seedlings are not known.

Plots were located between $1096 \mathrm{~m}$ and $1177 \mathrm{~m}$ in elevation. Although many plots were located at similar elevations, the mean elevation of unsalvaged plots was slightly higher. All plots were located on south- to west-facing slopes so that we could reduce variation in aspect and assess sites that caught the brunt of 
the blast. Slopes were not different between salvaged-replanted and unsalvaged plots, and many sites were quite steep.

Twenty-five 200- $\mathrm{m}^{2}$ circular plots in both salvaged-replanted and unsalvaged areas were assessed in July 2003. Slope and aspect were determined with compass and clinometer. Elevation and location were determined by a GPS (Garmin eTrex ${ }^{\circledR}$ Legend; UTM, NAD 1927). Percent cover and density of each plant species in each plot was estimated. A gridded $1-\mathrm{m}^{2}$ frame aided cover estimates. Height of each woody plant, including seedlings, was also measured. Density of clonal species was estimated. We identified species by referring to Hitchcock and Cronquist (1973) and Hickman (1993). Nomenclature was current in 2005 (Integrated Taxonomic Information System [ITIS]).

To obtain a coarse estimate of the quantity of downed woody debris (DWD), we used the line-intercept method on a randomly selected 16-m transect across each plot (van Wagner 1968), with diameter measured on each DWD diameter $>10 \mathrm{~cm}$. Diameters and numbers of snags, tip-ups, and stumps in each plot were also recorded. In each plot, soil was collected from the top $10 \mathrm{~cm}$ of 4 randomly selected sites and aggregated for a total of $500 \mathrm{~mL}$ of soil. Because of slopes, depth to pre-eruption soils varied dramatically (Titus personal observation). It appeared that on many of the sites pre-eruption soils were close to the surface. If loose, unconsolidated pumice was present at the sampling site, the soil samples were collected from below the loose pumice. Larger plants would most likely have their roots in pre-eruption soils, which could differ from the soils of the top $10 \mathrm{~cm}$. At each soil collection site, litter depth was recorded. Litter depth refers to the depth of the $\mathrm{L}, \mathrm{F}$, and $\mathrm{H}$ horizons (Agriculture Canada Expert System on Soil Survey 1987). The $\mathrm{F}$ and $\mathrm{H}$ horizons were poorly represented, and the $\mathrm{L}$ horizon composed the majority of the depth. Litter depths from the 4 sites were averaged to yield a mean plot litter depth.

Soil samples were analyzed for total nitrogen, nitrate, phosphorus, soil $\mathrm{pH}$, cation exchange capacity (CEC), and soil organic matter (TOC) at the Soil, Water, and Plant Analysis Laboratory in the Department of Soil, Water, and Environmental Science, University of Ari- zona. Total nitrogen was determined by the Kjeldahl method (McGill and Figueiredo 1993). Exchangeable nitrate levels were determined by cadmium reduction in $2.0 \mathrm{~N} \mathrm{KCl}$ extract (Maynard and Kalra 1993, Miller et al. 1998). Available phosphorus was determined by Olsen's procedure (Miller et al. 1998). Soil pH was determined by saturated paste (Miller et al. 1998), CEC by ammonium replacement (Miller et al. 1998), and TOC levels by loss on ignition (Miller et al. 1998). Although measured nitrate levels are not clear indicators of actual nitrate availability or flux rates (Stark and Hart 1997), the measured nitrate levels may at least illustrate overall trends in nitrate availability.

For salvaged-replanted and unsalvaged sites, we calculated mean percent plant cover, mean species richness, and mean diversity (ShannonWiener index, base $_{\mathrm{e}}$ ). For analysis, the aspect was converted to an exposure scale. This scale ranged from 1 for north-facing sites to 10 for exposed south-facing sites (Whittaker 1960).

We used detrended correspondence analysis (DCA) to obtain indirect ordinations of plots (Hill and Gauch 1980). The best plot and species spread in ordination space was achieved without data transformations and without downweighting the influence of rare species.

The relationships between measured environmental variables and the species-plot relationships were explored by canonical correspondence analysis (CCA), a constrained ordination method (ter Braak and Smilauer 1998). The correlation of each variable to canonical axes provided insights into factors that may control community structure. In general, the longer the environmental vector, the stronger the relationship of that variable with the community. The position of a species relative to an environmental vector can be used to interpret the relationship between various species and the measured environmental variables. We performed Monte Carlo permutation tests to determine if observed patterns differed from random. CANOPOST graphics were used (Smilauer 1993). Salvaged-replanted and unsalvaged treatments were passive in the analysis. In this way, patterns observed in the diagrams are not affected by the treatments; rather the patterns are due to measured environmental variables and species distributions in the plots. In the biplot, axis 1 represents the direction of the 
TABLE 1. Mean, standard deviation, and range of environmental variables in salvaged and unsalvaged plots on Mount St. Helens $(n=25)$. Salvage and unsalvaged plots were contrasted by independent samples $t$ tests at $\alpha=0.5$.

\begin{tabular}{|c|c|c|c|c|c|c|}
\hline & \multicolumn{2}{|c|}{ Salvaged plots } & \multicolumn{2}{|c|}{ Unsalvaged plots } & \multicolumn{2}{|c|}{ Statistics } \\
\hline & Mean & Range & Mean & Range & $t$-value & $P$ \\
\hline$\overline{\text { Elevation }(\mathrm{m})}$ & $1135 \pm 18$ & $1096-1168$ & $149 \pm 19$ & $1118-1177$ & -1.961 & 0.056 \\
\hline Aspect $\left(^{\circ}\right)^{\mathrm{a}}$ & $231 \pm 33$ & $160-290$ & $204 \pm 35$ & $148-264$ & -1.557 & 0.126 \\
\hline Slope $(\%)$ & $37 \pm 12$ & $16-60$ & $34 \pm 12$ & $17-62$ & 0.649 & 0.519 \\
\hline Litter depth $(\mathrm{cm})$ & $0.3 \pm 0.4$ & $0-1.8$ & $2.2 \pm 1.9$ & $0-6.5$ & -4.851 & $<0.001$ \\
\hline$\%$ litter cover & $29 \pm 17$ & $2-65$ & $38 \pm 26$ & $5-75$ & -1.454 & 0.154 \\
\hline$\%$ downed woody debris ${ }^{b}$ & $3.9 \pm 3.3$ & $1-12$ & $20.4 \pm 11.2$ & $6-50$ & -7.092 & $<0.001$ \\
\hline No. DWD $\cdot 16 \mathrm{~m}^{-1 \mathrm{c}}$ & $2.3 \pm 1.8$ & $0-6$ & $8.1 \pm 3.0$ & $5-13$ & -8.257 & $<0.001$ \\
\hline Average DWD diameter $(\mathrm{cm})^{\mathrm{d}}$ & $29 \pm 19$ & $0-65$ & $48 \pm 11$ & $28-68$ & -4.432 & $<0.001$ \\
\hline No. tip-ups & $0.8 \pm 1.4$ & $0-4$ & $2.4 \pm 1.8$ & $0-8$ & -3.578 & 0.001 \\
\hline Snags & $0.04 \pm 0.2$ & $0-1$ & $0.08 \pm 0.3$ & $0-1$ & -0.586 & 0.561 \\
\hline Stumps & $5.0 \pm 3.4$ & $0-17$ & $0.08 \pm 0.4$ & $0-2$ & 6.480 & $<0.001$ \\
\hline$\%$ bare area cover & $47 \pm 17$ & $14-75$ & $20 \pm 12$ & $4-50$ & 6.420 & $<0.001$ \\
\hline$\%$ moss cover & $8 \pm 6$ & $1-30$ & $3 \pm 2$ & $1-10$ & 4.192 & $<0.001$ \\
\hline$\%$ understory plant cover & $14 \pm 8$ & $4-32$ & $29 \pm 15$ & $8-68$ & -4.332 & $<0.001$ \\
\hline Understory richness ${ }^{\mathrm{e}}$ & $11 \pm 3$ & $6-17$ & $21 \pm 5$ & $8-29$ & -8.444 & $<0.001$ \\
\hline Understory diversity & $1.48 \pm 0.32$ & $0.86-2.07$ & $1.97 \pm 0.44$ & $0.64-2.60$ & -4.566 & $<0.001$ \\
\hline$\%$ nonnative species cover & $2.0 \pm 2.4$ & $0.1-10.0$ & $1.2 \pm 1.2$ & $0.1-4.0$ & 1.242 & 0.223 \\
\hline$\%$ total nitrogen & $0.016 \pm 0.0091$ & $0.0077-0.038$ & $0.021 \pm 0.010$ & $0.0097-0.046$ & -1.846 & 0.071 \\
\hline Nitrate $\left(\mu \mathrm{g} \cdot \mathrm{g}^{-1}\right)$ & $0.50 \pm 0.77$ & $0.15-3.45$ & $4.33 \pm 5.18$ & $0.15-18.50$ & -3.657 & 0.001 \\
\hline Phosphate $\left(\mu \mathrm{g} \cdot \mathrm{g}^{-1}\right)$ & $7.38 \pm 3.08$ & $2.00-15.66$ & $15.20 \pm 4.85$ & $7.28-26.18$ & -6.809 & $<0.001$ \\
\hline$\%$ soil organic matter & $0.50 \pm 0.32$ & $0.18-1.62$ & $0.56 \pm 0.25$ & $0.17-1.07$ & -0.667 & 0.508 \\
\hline
\end{tabular}

\footnotetext{
aAspect converted to Whittaker (1960) exposure classes for statistical analysis.

bPercent of the plot covered by downed woody debris $>10 \mathrm{~cm}$ in diameter.

${ }^{\mathrm{c}}$ Average number of downed woody debris $>10 \mathrm{~cm}$ in diameter encountered in a $16-\mathrm{m}$ transect across each plot.

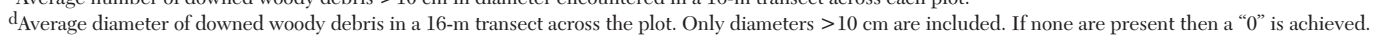

eThese analyses were conducted without the coniferous species Abies procera, Abies amabilis, Picea englemanii, Pinus monticola, Pseudotsuga menziesii, and

Tsuga heterophylla. Broad-leafed trees (Populus balsamifera, Salix sitchensis, and Alnus viridis) were present as saplings and were included in the analysis.
}

greatest amount of variation, and axis 2 represents the 2nd-greatest amount of variation in the data set.

\section{Results}

Salvaged-replanted and unsalvaged sites were significantly different for most of the measured variables (Table 1). Unsalvaged plots had overall more DWD. Unsalvaged plots had more tip-ups than salvaged-replanted plots and salvaged-replanted plots had, as expected, more stumps. Unsalvaged plots had deeper litter, whereas salvaged plots had a greater percentage of bare soil and moss cover. Unsalvaged plots had more herb and shrub cover and were richer and more diverse than salvaged-replanted plots. A total of 90 species were found in all of the plots (Appendix); 52 species were found in salvaged-replanted plots and 78 species were found in unsalvaged plots. Along with the greater cover of herbs and shrubs in unsalvaged sites, herb and shrub richness and diversity were also higher. Collectively, unsalvaged plots contained more species in various life-form groups than did salvagedreplanted plots (Table 2). All of the species detected are common species of the region (Hitchcock and Cronquist 1973, Franklin and Dyrness 1988, Titus et al. 1998).

Chamerion angustifolium, Hieracium albiflorum, Anaphalis margaritacea, Hypochaeris radicata, and Vaccinium membranaceum were found in more than $80 \%$ of the salvagedreplanted plots, and the last 3 species were found in every plot (Table 3). Hypochaeris radicata, Hieracium albiflorum, V. membranaceum, A. margaritacea, and C. angustifolium were found in more than $80 \%$ of unsalvaged plots, and the last 2 species were found in every plot. Abies procera was found in 22 of the 25 salvaged-replanted plots and in none of the unsalvaged plots (Table 4). The 3 salvaged-replanted plots without A. procera canopy cover did not differ from other salvaged-replanted plots in terms of herb and shrub composition or soil characteristics. Abies amabilis was found in 14 of the 25 unsalvaged plots and was not found in salvaged-replanted plots, whereas 
TABle 2. Number of species in life-form groups in salvaged and unsalvaged plots on Mount St. Helens $(n=25)$. The nonnative species are all forbs, except for 1 grass, and are included in both their respective categories.

\begin{tabular}{lcc}
\hline & \multicolumn{2}{c}{ Number of species } \\
\cline { 2 - 3 } Life-form & Salvaged & Unsalvaged \\
\hline Total species & 52 & 80 \\
Conifers & 5 & 4 \\
Broad-leafed trees & 2 & 3 \\
Shrubs & 9 & 12 \\
Forbs & 22 & 38 \\
Grasses & 11 & 18 \\
Ferns & 3 & 5 \\
Nonnative species & 4 & 6 \\
\hline
\end{tabular}

Pseudotsuga menziesii was found in 8 salvagedreplanted plots and in 9 unsalvaged plots. Deciduous trees, which often dominate successional forests in the region, were more common in unsalvaged plots (Table 4). Every plot contained nonnative species, mostly at low cover (Table 5). Unsalvaged plots contained 6 nonnative species overall, and salvagedreplanted plots contained 4 nonnative species. Salvaged-replanted and unsalvaged plots did not differ in nonnative species cover (Table 1).

The greater species richness and variety in species composition of unsalvaged plots is apparent in the DCA (Fig. 2). The environmental factors with the greatest difference between salvaged-replanted and unsalvaged sites are clearly seen in the CCA; this shows that the environments of salvaged-replanted and unsalvaged plots differ markedly (Fig. 3). Elevation, slope, and aspect do not appear to be important in structuring the vegetation; that is, they are not correlated with the other factors.

In the DCA analysis, 29 species that occurred in only 1 or 2 plots were excluded. These uncommon species were predominantly from unsalvaged plots and had little effect on the ordination (Fig. 2). The 2 axes in this ordination are 3.1 and 2.4 half-changes long, which are indicative of a data set with a moderate range of species composition (Table 6). In Figure 2 the salvaged-replanted plots are located below the unsalvaged plots and are more tightly clustered, showing that they exhibit less variation in species composition than do unsalvaged plots. The reduced variation of salvaged-replanted plots is evident in the smaller standard deviations of the plot scores for salvaged-replanted plots (axis 1: $s=0.507$; axis 2 : $s=0.335$ ) than for unsalvaged plots (axis $1: s$ $=0.742$; axis $2: s=0.448$ ).

In Figure 2 the unsalvaged outlier plot on the far right-hand side of the horizontal axis was dominated by Pteridium aquilinum and the unsalvaged plot outlier at the top of the vertical axes was dominated by the ruderals $C$. angustifolium and A. margaritacea and by Rubus lasiococcus. Species that were important in unsalvaged plots occur in the top left and far right portions of the ordination diagram. Species that are common in both salvaged-replanted and unsalvaged plots occur in the central portion of the diagram.

In the CCA, the variable "number of snags" was removed because snags were infrequent (Fig. 3). The environmental attributes of salvaged-replanted plots can be seen in the lower left quadrant with the correlation between stumps and bare area, both of which had significantly higher values in salvaged-replanted plots than in unsalvaged plots. Likewise, the species mostly found in salvaged-replanted sites are in this quadrant. Most species found in unsalvaged plots are in the upper right quadrant. In addition, the majority of the infrequent species excluded from the analysis were also in unsalvaged plots. Thicker litter, higher phosphorus levels, and more DWD are associated with unsalvaged plots, along with weaker trends for higher levels of total nitrogen, nitrate, litter cover, TOC, and more tipups. Elevation, slope, and aspect vectors are at right angles to the other variables, indicating the lack of correlation of these 3 factors to the other site factors. Steeper slopes are correlated with higher elevations. A few species that were found in the higher elevation plots on steep slopes are located in the lower right quadrant; these were unsalvaged plots. The first 2 axes explain $55 \%$ of the relationship between species and the environment.

The nitrogen fixers (Alnus and Lupinus) are not related to the nitrogen axes in any of the analyses, meaning that these species are not found in areas of higher nitrogen. Nonnative species do not cluster in any of the analyses. The CCA was significant by the Monte Carlo test.

\section{DisCUSSION}

The differences found in environmental factors and species distributions, richness, and 
TABLE 3. Non-tree species in salvaged and unsalvaged plots on Mount St. Helens with $>50 \%$ frequency and $>1 \%$ mean cover $(n=25)$. Mean cover is the average of all 25 plots.

\begin{tabular}{|c|c|c|c|c|}
\hline \multirow[b]{2}{*}{ Species } & \multicolumn{2}{|c|}{ Salvaged plots } & \multicolumn{2}{|c|}{ Unsalvaged plots } \\
\hline & $\%$ frequency & $\%$ mean cover & $\%$ frequency & $\%$ mean cover \\
\hline Vaccinium membranaceum & 100 & 4.5 & 96 & 5.5 \\
\hline Anaphalis margaritacea & 100 & 2.2 & 100 & 5.2 \\
\hline Hypochaeris radicata & 100 & 2.0 & 92 & 1.1 \\
\hline Eriogonum pyrolifolium & 60 & 2.0 & 28 & 0.4 \\
\hline Vaccinium ovalifolium & 52 & 1.5 & 80 & 2.0 \\
\hline Menziesii ferruginea & 24 & 0.3 & 40 & 0.2 \\
\hline Epilobium minutum & 48 & 0.5 & 44 & 0.3 \\
\hline Hieracium albiflorum & 96 & 0.2 & 96 & 0.5 \\
\hline Chamerion angustifolium & 88 & 0.1 & 100 & 3.4 \\
\hline Pteridium aquilinum & 0 & 0 & 16 & 2.7 \\
\hline Rubus lasiococcus & 0 & 0 & 60 & 0.7 \\
\hline Polystichum munitum & 28 & 0.05 & 80 & 0.4 \\
\hline Athyrium filix-femina & 12 & 0.01 & 64 & 0.3 \\
\hline Sorbus sitchensis & 8 & 0.004 & 48 & 0.3 \\
\hline Luzula parviflora & 12 & 0.02 & 76 & 0.2 \\
\hline Agrostis scabra & 36 & 0.1 & 64 & 0.06 \\
\hline
\end{tabular}

aNonnative species

TABLE 4. Frequency, mean percent canopy cover, and mean density (trees $\cdot 200 \mathrm{~m}^{-2}$ ) of tree species in salvaged and unsalvaged plots on Mount St. Helens $(n=25)$.

\begin{tabular}{lccccccc}
\hline & \multicolumn{3}{c}{ Salvaged plots } & & \multicolumn{3}{c}{ Unsalvaged plots } \\
\cline { 2 - 4 } Species & \% freqency & \% cover & Density & & \% frequency & \% cover & Density \\
\hline Abies amabilis & 0 & 0 & 0 & & 56 & 3.0 & 1.8 \\
Abies procera & 16 & 22.5 & 17 & & 0 & 0 & 0 \\
Alnus viridis & 4 & 0.2 & 0.72 & & 56 & 2.0 & 2.0 \\
Picea englemannii & 12 & 0.2 & 0.08 & & 0 & 0 & 0 \\
Pinus monticola & 0 & 0 & 0.12 & & 8 & 0.02 & 0.08 \\
Populus balsamifera & 32 & 0.1 & 0.6 & & 36 & 0.06 & 0.21 \\
Pseudotsuga menziesii & 40 & 0.2 & 0.64 & & 72 & 1.3 & 0.54 \\
Salix sitchensis & 12 & 0.1 & 0.2 & & 16 & 0.3 & 2.8 \\
Tsuga heterophylla & 12 & &
\end{tabular}

TABLE 5. Nonnative species in salvaged and unsalvaged plots on Mount St. Helens $(n=25)$. Percent cover is a mean based only on plots that contained the species.

\begin{tabular}{lccccc}
\hline \multirow{2}{*}{ Species } & \multicolumn{2}{c}{ Salvaged plots } & & \multicolumn{2}{c}{ Unsalvaged plots } \\
\cline { 2 - 3 } \cline { 5 - 6 } & \% frequency & \% cover (range) & & \% frequency & \% cover (range) \\
\hline Hypochaeris radicata & 100 & $1.9(0.1-10)$ & & 92 & $1.2(0.1-3)$ \\
Lactuca muralis & 4 & $0.01(0.01)$ & & 44 & $0.2(0.01-0.5)$ \\
Anthoxanthum odoratum & 12 & $0.2(0.01-0.5)$ & & 48 & $0.4(0.01-2)$ \\
Cirsium arvense & 8 & $0.1(0.1)$ & 0 & 12 & $0.07(0.01-0.1)$ \\
Senecio jacobea & 0 & 0 & 4 & $0.1(0.1)$ \\
Spergularia rubra & 0 & $2.3(0.1-10)$ & & 100 & $0.01(0.01)$ \\
TotaL & 100 & & & & $1.9(0.1-4)$ \\
\hline
\end{tabular}




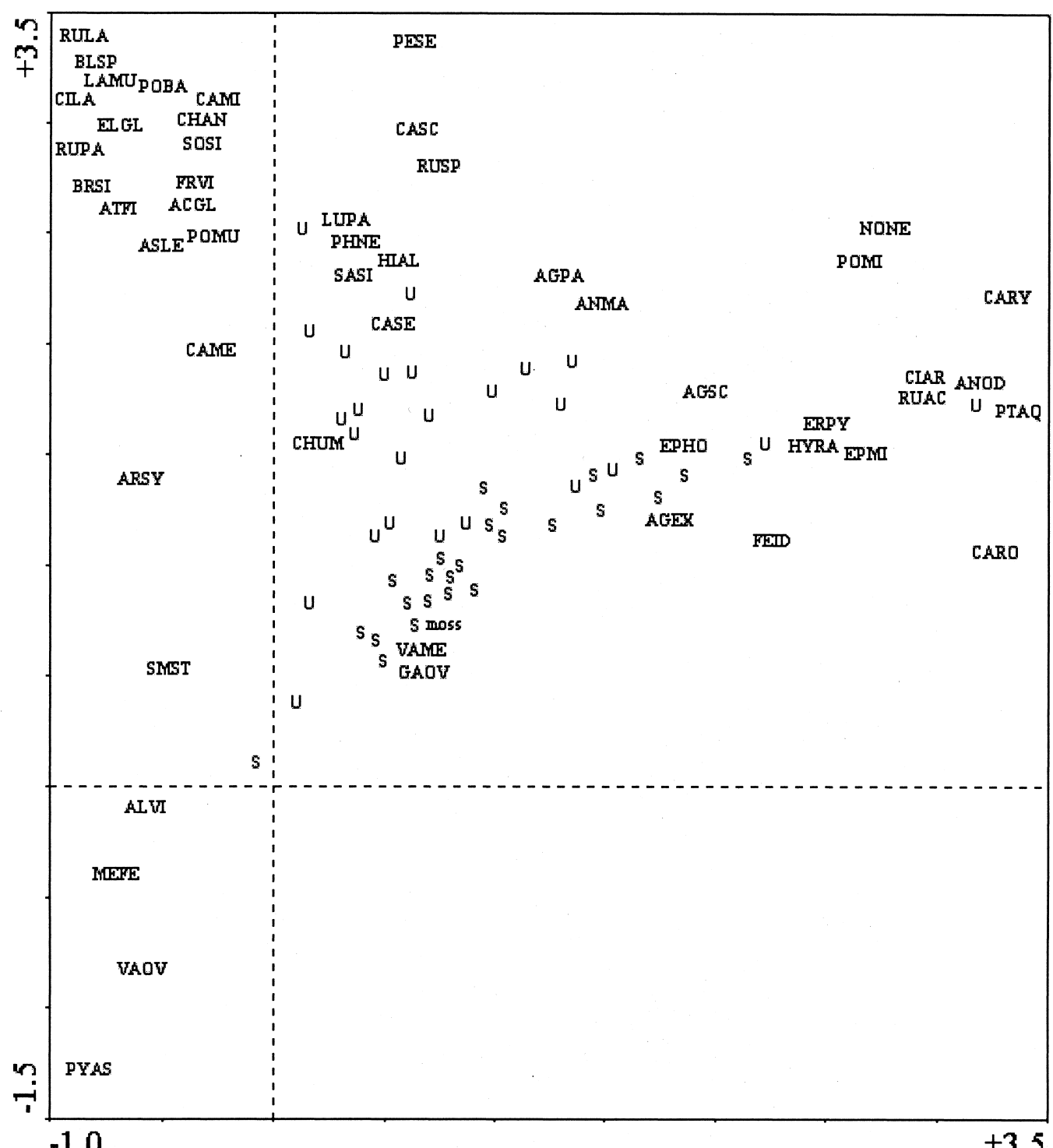

Fig. 2. Detrended correspondence analysis plot of salvaged-replanted plots (S) and unsalvaged plots (U) on Mount St. Helens. Infrequent species have been removed. The 4-letter species abbreviations are defined in the Appendix. Salvaged-replanted plots are closer to each other on the diagram, indicating that their species compositions are more similar.

diversity show that salvage logging and replanting affected vegetation and to a lesser extent soils 23 years post-disturbance and 20 years post-salvage and planting. This is not only due to the overstories, which have completely different compositions because Abies procera has been planted in the salvaged sites and is not present in the sparse canopy of the unsalvaged sites, but also to the understories, which differ dramatically. Unsalvaged plots have higher herb and shrub diversity and cover. Soils are also quite different between the 2 treatments. The soils of unsalvaged plots have higher levels of nitrate and phosphorus than soils of salvaged-replanted sites. It may be that less phosphorus is present in salvaged-replanted sites because of uptake by ectomycorrhizal fungi connected to the young noble fir. In addition, salvaged-replanted plots have a greater amount of unvegetated soil surface and moss 


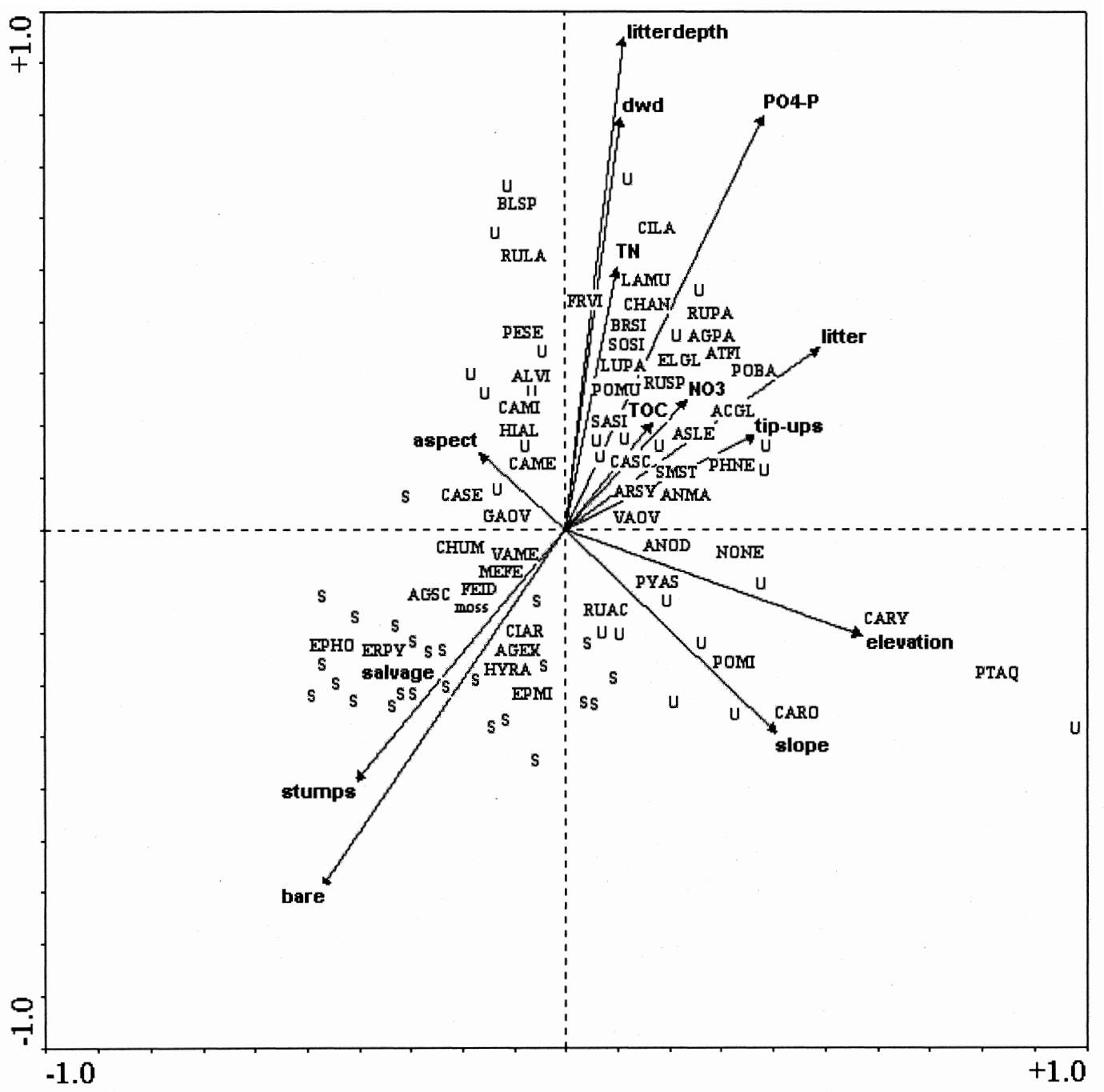

Fig. 3. Canonical correspondence analysis diagram of species and plots in salvaged-replanted sites (S) and unsalvaged sites (U) on Mount St. Helens. Infrequent species have been removed. The "salvage" and "unsalvaged" environmental variables are passive. The 4-letter species abbreviations are defined in the Appendix. The longer the environmental vector, the stronger the relationship of that variable on the data set. The position of a species or plot relative to an environmental vector can be used to interpret the relationship between various species and the measured environmental variables. For example, unsalvaged plots have higher nutrient levels and more litter. See text for further explanation.

cover. All these differences may be partially attributable to the fact that DWD quantity is greater in unsalvaged plots (Table 1). Across much of the unsalvaged sites, downed trees were situated at right angles to the slope, and it was common to see a large quantity of soil piled up behind DWD and plants clustered above and below the DWD. Perhaps seeds are more effectively retained in unsalvaged plots. However, evidence of erosion, such as rills and gullies, was not present in the salvaged- replanted sites. Woody debris shades the soil, creating cooler, moister surface soil conditions and thereby creating microsite conditions more conducive to seedling survival (Rumbaitis-del Rio 2006). However, as the Abies procera canopies close, the shade they cast may make up for the lack of DWD.

Although salvaged-replanted sites and unsalvaged sites were located in different areas, with the salvaged-replanted sites at lower elevations and slightly more westerly facing, these 
TABLE 6. Summary of the detrended correlation analysis (DCA) axes, the canonical correlation analysis (CCA) axes, and Monte Carlo significance test results. The axis-2 column is trace for Monte Carlo results.

\begin{tabular}{|c|c|c|c|c|}
\hline \multirow[b]{2}{*}{ Variable } & \multicolumn{2}{|c|}{ DCA all plots } & \multicolumn{2}{|c|}{ CCA all plots } \\
\hline & Axis 1 & Axis 2 & Axis 1 & Axis 2 \\
\hline Eigenvalues & 0.725 & 0.461 & 0.443 & 0.350 \\
\hline Length of gradient & 3.086 & 2.405 & & \\
\hline Species-environment correlation & & & 0.829 & 0.880 \\
\hline$\%$ variance of species data & 23.3 & 9.6 & 14.2 & 11.3 \\
\hline$\%$ variance of spp.-env. relation & & 30.8 & 24.3 & \\
\hline Unconstrained eigenvalues & \multirow{3}{*}{\multicolumn{2}{|c|}{3.115}} & \multirow{3}{*}{\multicolumn{2}{|c|}{$\begin{array}{c}3.115 \\
1.440 \\
46.2\end{array}$}} \\
\hline Constrained eigenvalues & & & & \\
\hline$\%$ & & & & \\
\hline Monte Carlo $P$ & & & 0.030 & 0.005 \\
\hline
\end{tabular}

differences are not considered large enough to have caused any of the observed variation in vegetation and soil nutrients. We observed that nearby intact forests in the Cascades do not show vegetational differences across an elevational gradient of $<100 \mathrm{~m}$ at this elevation. The force of the eruption may have been greater in the unsalvaged sites, as indicated by the greater number of tip-ups. In any case, most trees in the salvaged-replanted plots died standing and were subsequently logged, leaving behind a stump.

Because of the litter generated by A. procera on salvaged-replanted sites, litter cover did not differ between salvaged-replanted and unsalvaged sites (Table 1). However, litter was much deeper in unsalvaged sites probably because of the greater retention of litter in these sites and the greater quantity of broadleafed species generating litter. This could potentially result in long-term differences in nutrient cycling between salvaged-replanted and unsalvaged sites.

Regardless of whether sites are salvaged, surface soils had much lower organic matter levels than soils of undisturbed forests in the region (Franklin and Dyrness 1988). This was due to the deposition of tephra. However, organic matter levels were much higher than the $<0.01 \%$ soil organic matter found in primary successional sites on the Pumice Plains, where $>100 \mathrm{~m}$ of tephra was deposited (del Moral 1999, Titus unpublished data).

In the unsalvaged plots, greater litter depth is positively correlated with phosphorus and total nitrogen, and weakly correlated with TOC (Fig. 3). Although axis 1 illustrates the strongest patterns in species distributions, many species are also responding to the environmental factors of axis 2 and are distributed along this axis. The nitrogen fixers (Alnus and Lupinus) are not related to the nitrogen vectors in any of the CCA diagrams, perhaps because they are never sufficiently prevalent to affect nitrogen levels.

There were no differences in nonnative species between salvaged-replanted and unsalvaged plots. The nonnative species found here are common in clear-cuts throughout the region, and they invade, but do not dominate, the highly disturbed environments created by the eruption, whether or not salvage has occurred. Nonnative species do not cluster in any of the CCAs, indicating that each species is responding differently to environmental conditions. In other environments, such as Florida scrub (Greenberg et al 1995), nonnative species are prevalent in salvaged sites. This was not the case here. Hypochaeris radicata, the most common nonnative species in this study (Table 5), is prevalent on successional sites across the volcano. Nonnative species may alter the trajectory of succession at many successional sites (Vitousek and Walker 1989, Titus and Tsuyuzaki 2003). However, the facts that $H$. radicata cover is generally low in most plots and that it has decreased in other areas on Mount St. Helens (Titus unpublished data) reduce the probability of major changes to vegetation composition from this species.

If it was the case that some of the salvagedreplanted area was clear-cut before the eruption, then this treatment did not cause a wide 
discrepancy in species cover among the salvaged-replanted plots (Fig. 2). Clear-cuts in the region are dominated by many of the species that are prevalent in the unsalvaged plots. Because both the salvage logging and the subsequent planting of noble fir occurred on all but 3 of the salvaged plots, it was difficult to separate the effects of the salvage logging from the effects of the developing noble fir. However, the 3 plots, which did not contain any A. procera, did not differ in terms of herb and shrub composition from those with A. procera cover. This result suggests that differences between treatments were likely due to logging activities rather than planting. In any case, the combination of the 2 treatments has led to reduced diversity and cover, completely different overstory species composition, and lower nutrient levels in salvaged sites at this time. We predict that salvaged and unsalvaged sites will remain very different for a long time to come. Not only will the overstories continue to have very different compositions, but understory species will struggle to establish themselves in salvaged sites when the planted noble fir achieves a closed canopy. Salvage logging will continue to be planned for post-disturbance forest lands; therefore, it is important that land managers understand the effects that this management tool will have on forest composition and structure. Because large, naturally reforesting areas are rare not only in the Pacific Northwest but worldwide, and because they are important for regional biodiversity, unsalvaged sites are an important natural laboratory for observing successional processes and are worthy of conservation interest.

\section{ACKNOWLEDGMENTS}

This work was supported by U.S. National Science Foundation grant DEB-0089843 to J. Bishop and J.H. Titus. We thank the Mount St. Helens National Volcanic Monument for permission to conduct field research and the Biosphere 2 Center for logistical support. C. Rumbaitis-del Rio provided invaluable ideas on field research and on the manuscript. The manuscript was greatly improved by comments from J. Bishop, R. del Moral, and anonymous reviewers. Thanks go to J. Seeds, S. Wills, and S. Yang for field camp support. We are grateful to P. Titus and L. Gephart for generous encouragement and support.

\section{Literature Cited}

Agriculture Canada Expert System on Soil Survey. 1987. The Canadian system of soil classification. 2nd edition. Agriculture Canada Publication 1646. 164 pp.

Amaranthus, M., H. Jubas, And A. David. 1989. Stream shading, summer streamflow and maximum water temperature following intense wildfire in headwater streams. Pages 75-78 in N.H. Berg, technical coordinator, Proceedings of the symposium on fire and watershed management, Oct. 26-28, 1988, Sacramento, CA. General Technical Report PSW-109, USDA Forest Service, Pacific Southwest Forest and Range Experiment Station, Berkeley, CA. Cited in J.D. McIver and L. Starr, editors. 2000. Environmental effects of postfire logging: literature review and annotated bibliography. General Technical Report PNW-GTR-486, USDA Forest Service, Pacific Northwest Research Station, Portland, OR. Accessed October 2004. Available from: www.fs.fed.us/pnw/.

Chou, Y.H., S.G. CONRAD, AND P.M. WOHLGEMUTH. 1994a. Analysis of postfire salvage logging on sedimentation, watershed characteristics, and sedimentation in the Stanislaus National Forest. Pages 492-499 in Proceedings of ESRI users conference, 1994, Palm Springs, CA. Cited in J.D. McIver and L. Starr, editors. 2000. Environmental effects of postfire logging: literature review and annotated bibliography. General Technical Report PNW-GTR-486, USDA Forest Service, Pacific Northwest Research Station, Portland, OR. Accessed October 2004. Available from: www.fs.fed.us/pnw/.

. 1994b. Postfire salvage logging variables and basin characteristics related to sedimentation, Stanislaus National Forest. Pages 838-878 in Proceedings of GIS '94 Symposium, February 1994, Vancouver, BC. Cited in J.D. McIver and L. Starr, editors. 2000. Environmental effects of postfire logging: literature review and annotated bibliography. General Technical Report PNW-GTR-486, USDA Forest Service, Pacific Northwest Research Station, Portland, OR. Accessed October 2004. Available from: www.fs.fed. us/pnw/.

Dale, V.H., F.J. Swanson, and C.M. Crisafulli. 2005. Ecological perspectives on management of the Mount St. Helens landscape. Pages 277-286 in V.H. Dale, F.J. Swanson, and C.M. Crisafulli, editors, Ecological responses to the 1980 eruption of Mount St. Helens. Springer, New York.

DEL Moral, R. 1999. Plant succession on pumice at Mount St. Helens. American Midland Naturalist 141:101114.

Donato, D.C., J.B. Fontaine, J.L. Campbell, W.D. RobinSon, J.B. Kauffman, and B.E. LaW. 2006. Post-wildfire logging hinders regeneration and increases fire risk. Science 311:352.

Franklin, J.F., AND C.T. Dyrness. 1988. Natural vegetation in Oregon and Washington. Oregon State University Press, Corvallis.

Franklin, J.F., D.B. Lindenmayer, J.A. MacMahon, A. McKee, J. Magnuson, D.A. Perry, R. Waide, and D. Foster. 2000. Threads of continuity: ecosystem disturbances, biological legacies and ecosystem recovery. Conservation Biology in Practice 1:8-16.

GreenberG, C.H., D.G. Neary, L.D. Harris, and S. Linda. 1995. Vegetation recovery following high-intensity 
wildfire and silvicultural treatments in sand pine scrub. American Midland Naturalist 133:149-163.

Helvey, J.D., A.R. Tiedemann, and T.D. Anderson. 1985. Plant nutrient losses by soil erosion and mass movement after wildfire. Journal of Soil and Water Conservation 40:168-173.

Hickman, J.C. 1993. The Jepson manual: higher plants of California. University of California Press, Berkeley.

Hill, M.O., and H.G. GaUCH, JR. 1980. Detrended correspondence analysis, an improved ordination technique. Vegetation 42:47-48.

Hitchcock, C.L., AND A. Cronquist. 1973. Flora of the Pacific Northwest. University of Washington Press, Seattle.

Lindenmayer, D.B., D.R. Foster, J.F. Franklin, M.L. Hunter, R.F. Noss, F.A. Schmiegelow, and D. Perry. 2004. Salvage harvesting policies after natural disturbance. Science 303:1303.

Maloney, P.C., J.L. Thornton, and E. Lesch. 1995. Executive summary: summary of watershed monitoring within the Foothills Fire salvage logging area 1992-1995. USDA Forest Service, Boise National Forest, Boise, ID. Cited in J.D. McIver and L. Starr, editors. 2000. Environmental effects of postfire logging: literature review and annotated bibliography. General Technical Report PNW-GTR-486, USDA Forest Service, Pacific Northwest Research Station, Portland, OR. Accessed October 2004. Available from: www.fs.fed.us/pnw/.

Marston, R.A., And D.H. Haire. 1990. Runoff and soil losses following the 1988 Yellowstone fires. Great Plains-Rocky Mountain Geographical Journal 18:1-8.

Maynard, D.G., and Y.P. Kalra. 1993. Nitrate and exchangeable ammonium nitrogen. Pages 25-38 in M.R. Carter, editor, Soil sampling and methods of analysis. Lewis Publishers, Ann Arbor, MI.

McGill, W.B., And C.T. Figueiredo. 1993. Total nitrogen. Pages 201-202 in M.R. Carter, editor, Soil sampling and methods of analysis. Lewis Publishers, Ann Arbor, MI.

MCIVER, J.D., AND L. STARR, EDITORS. 2000. Environmental effects of postfire logging: literature review and annotated bibliography. General Technical Report PNW-GTR-486, USDA Forest Service, Pacific Northwest Research Station, Portland, OR. Accessed October 2004. Available from: www.fs.fed.us/pnw/.

Miller, R.O., J. Kotuby-Amacher, and J.B. Rodriguez. 1998. Western States Laboratory Proficiency Testing Program: Soil and Plant Analytic Methods, version 4.10. WREP 125, Logan, UT.

Paine, R.T., M.J. Tegner, and E.A. Johnson. 1998. Compound perturbations yield ecological surprises. Ecosystems 1:535-545.

Rumbaitis-Del Rio, C.M. 2006. Changes in understory composition following catastrophic windthrow and salvage-logging in a subalpine forest ecosystem. Canadian Journal of Forest Research. 36:2943-2954.
SEXTON, T.O. 1994. Ecological effects of post-wildfire salvage-logging on vegetation diversity, biomass, and growth and survival of Pinus ponderosa and Purshia tridentata. Oregon State University, Department of Rangeland Resources, Corvallis. Unpublished manuscript. Cited in J.D. McIver and L. Starr, editors. 2000. Environmental effects of postfire logging: literature review and annotated bibliography. General Technical Report PNW-GTR-486, USDA Forest Service, Pacific Northwest Research Station, Portland, OR. Accessed October 2004. Available from www.fs. fed.us/pnw/.

Smilauer, P. 1993. CanoDraw 3.0. Environmental Change Research Centre, University College, London.

Stark, J.M., and S.C. HaRT. 1997. High rates of nitrification and nitrate turnover in undisturbed coniferous forests. Nature 385:61-64.

STOKSTAD, E. 2006. Salvage logging research continues to generate sparks. Science 311:761.

Stuart, J.D., M.C. Grifantini, and L. Fox, III. 1993. Early sucessional pathways following wildfire and subsequent silvicultural treatment in Douglas-fir/ hardwood forests, NW California. Forest Science 39: 561-572.

Swanson, F.J., C.M. Crisafulli, and D.K. Yamaguchi. 2005. Geological and ecological settings of Mount St. Helens before May 18, 1980. Pages 13-26 in V.H. Dale, F.J. Swanson, and C.M. Crissafulli, editors, Ecological responses to the 1980 eruption of Mount St. Helens. Springer, New York.

TER BraAk, C.J.F., and P. SMilauer. 1998. CANOCO reference manual and user's guide to CANOCO for Windows software for canonical community ordination, version 4. Microcomputer Power, Ithaca, NY.

Titus, J.H., S. Moore, M. ARnot, And P.J. Titus. 1998. Inventory of the vascular flora of the blast zone, Mount St. Helens, Washington. Madroño 45:146-161.

Titus, J.H., AND S. TsuyuZaKi. 2003. Influence of a nonnative invasive tree on primary succession at $\mathrm{Mt}$. Koma, Hokkaido, Japan. Plant Ecology 169:307-315.

van Nieuwstadt, M.G.L., D. Sheil, and K. KaRTawinata. 2001. The ecological consequences of logging in the burned forests of East Kalimantan, Indonesia. Conservation Biology 15:1183-1186.

Van Wagner, C.E. 1968. The line intersect method in forest fuel sampling. Forest Science 14:20-26.

Vitousek, P.M., AND L.R. Walker. 1989. Biological invasion by Myrica faya in Hawaii: plant demography, nitrogen fixation, and ecosystem effects. Ecological Monographs 59:247-265.

WhitTaker, R.H. 1960. Vegetation of the Siskiyou Mountains, Oregon and California. Ecological Monographs 30:279-338.

Received 12 December 2005 Accepted 27 October 2006 
APPENDIX. Species at salvaged and unsalvaged sites on Mount St. Helens. Species without a 4-letter abbreviation are either conifer species or infrequent and not represented on an ordination diagram.

\begin{tabular}{|c|c|}
\hline Abbreviation & Species name \\
\hline ACGL & $\begin{array}{l}\text { Abies amabilis } \\
\text { Abies procera } \\
\text { Acer glabrum } \\
\text { Achillea millefolium } \\
\text { Achlys triphylla } \\
\text { Agoseris aurantica } \\
\text { Agoseris grandiflora }\end{array}$ \\
\hline AGEX & Agrostis exerata \\
\hline AGPA & Agrostis pallens \\
\hline AGSC & Agrostis scabra \\
\hline ALVI & $\begin{array}{l}\text { Alnus viridis } \\
\text { Amelanchier alnifolia }\end{array}$ \\
\hline ANMA & $\begin{array}{l}\text { Anaphalis margaritacea } \\
\text { Antennaria rosea }\end{array}$ \\
\hline ANOD & $\begin{array}{l}\text { Anthoxanthum odoratum } \\
\text { Arnica latifolia }\end{array}$ \\
\hline ARSY & Aruncus sylvestre \\
\hline ASLE & Aster ledophyllus \\
\hline ATFI & Athyrium filix-femina \\
\hline BLSP & Blechnum spicant \\
\hline BRSI & $\begin{array}{l}\text { Bromus sitchensis } \\
\text { Calamagrostis canadensis } \\
\text { Calamagrostis purpurescens }\end{array}$ \\
\hline CASE & Calamagrostis sesquiflora \\
\hline CASC & Campanula scouleri \\
\hline CAME & $\begin{array}{l}\text { Carex mertensii } \\
\text { Carex pachystachya }\end{array}$ \\
\hline CARO & Carex rossi \\
\hline CARY & Caryophyllacea sp. \\
\hline CAMI & Castilleja miniata \\
\hline CHAN & Chamerion angustifolium \\
\hline CHUM & Chimaphila umbellata \\
\hline CILA & Cinna latifolia \\
\hline CIAR & $\begin{array}{l}\text { Cirsium arvense } \\
\text { Clermontia parviflora (Montia) } \\
\text { Cystopteris fragilis } \\
\text { Deschampsia atropurpurea } \\
\text { Deschampsia elongata }\end{array}$ \\
\hline ELGL & Elymus glaucus \\
\hline ЕРНO & Epilobium hornemannii \\
\hline EPMI & Epilobium minutum \\
\hline ERPY & Eriogonum pyrolifolium \\
\hline FEID & Festuca idahoensis \\
\hline FRVI & Fragaria virginiana \\
\hline
\end{tabular}

Appendix. Continued.

\begin{tabular}{|c|c|}
\hline Abbreviation & Species name \\
\hline GAOV & $\begin{array}{l}\text { Gaultheria ovatifolia } \\
\text { Glyceria elata } \\
\text { Gnaphalium canadensis }\end{array}$ \\
\hline HIAL & $\begin{array}{l}\text { Hieracium albiflorum } \\
\text { Holodiscus discolor }\end{array}$ \\
\hline HYRA & Hypochaeris radicata \\
\hline LAMU & Lactuca muralis \\
\hline LUPA & Luzula parviflora \\
\hline MEFE & $\begin{array}{l}\text { Menziesia ferruginea } \\
\text { Mitella breweri }\end{array}$ \\
\hline moss & moss \\
\hline NONE & $\begin{array}{l}\text { Nothochelone nemorosa } \\
\text { Orthilia secunda (Pyrola) } \\
\text { Pachistima myrsinites } \\
\text { Penstemon cardwellii }\end{array}$ \\
\hline PESE & $\begin{array}{l}\text { Penstemon serrulatus } \\
\text { Petasites frigidus }\end{array}$ \\
\hline PHNE & $\begin{array}{l}\text { Phacelia nemerosa } \\
\text { Picea engelmannii } \\
\text { Pinus monticola }\end{array}$ \\
\hline POMI & Polygonum minimum \\
\hline POMU & Polystichum munitum \\
\hline POBA & $\begin{array}{l}\text { Populus balsamifera } \\
\text { Pseudotsuga menziesii }\end{array}$ \\
\hline PTAQ & Pteridium aquilinum \\
\hline PYAS & $\begin{array}{l}\text { Pyrola asarifolia } \\
\text { Ribes lacustre }\end{array}$ \\
\hline RULA & $\begin{array}{l}\text { Rubus lasiococcus } \\
\text { Rubus leucodermis }\end{array}$ \\
\hline RUPA & Rubus parviflorus \\
\hline RUSP & Rubus spectabilis \\
\hline RUAC & Rumex acetosella \\
\hline SASI & $\begin{array}{l}\text { Salix sitchensis } \\
\text { Sambucus racemosa } \\
\text { Senecio jacobea } \\
\text { Senecio triangularis }\end{array}$ \\
\hline SMST & Smilicina stellata \\
\hline SOSI & $\begin{array}{l}\text { Sorbus sitchensis } \\
\text { Spergularia rubra } \\
\text { Trisetum spicatum } \\
\text { Tsuga heterophylla } \\
\text { unkown forb species }\end{array}$ \\
\hline VAME & Vaccinium membranaceum \\
\hline VAOV & $\begin{array}{l}\text { Vaccinium ovatum } \\
\text { Vaccinium parviflorum } \\
\text { Valarian sitchensis }\end{array}$ \\
\hline
\end{tabular}

